\title{
INTERNATIONAL HANDBOOK OF RESEARCH ON ENVironmental Education
}

The environment and contested notions of sustainability are increasingly topics of public interest, political debate, and legislation across the world. Environmental education journals now publish research from a wide variety of methodological traditions that show linkages between the environment, health, development, and education. The growth in scholarship makes this an opportune time to review and synthesize the knowledge base of the environmental education (EE) field.

The purpose of this 51-chapter handbook is not only to illuminate the most important concepts, findings, and theories that have been developed by $\mathrm{EE}$ research, but also to examine critically the historical progression of the field, its current debates and controversies, what is still missing from the EE research agenda, and where that agenda might be headed.

Published for the American Educational Research Association (AERA) by Routledge Publishers.

Robert B. Stevenson, James Cook University, Australia

Michael Brody, Montana State University, USA

Justin Dillon, King's College London, UK

Arjen E.J. Wals, Wageningen University, The Netherlands 



\section{INTERNATIONAL HANDBOOK OF RESEARCH ON Environmental Education}

Edited by

Robert B. Stevenson

Michael Brody

Justin Dillon

Arjen E.J. Wals

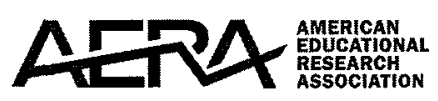

$$
\begin{aligned}
& \text { Routledge } \\
& \text { Taylor \& Francis Group } \\
& \text { NEW YORK AND LONDON }
\end{aligned}
$$


The American Educational Research Association (AERA) publishes books and journals based on the highest standards of professional review to ensure their quality, accuracy, and objectivity. Findings and conclusions in publications are those of the authors and do not reflect the position or policies of the Association, its Council, or its officers.

\section{(C) 2013 American Educational Research Association}

The AERA Books Editorial Board

Chair: Cherry A. McGee Banks

Members: D. Jean Clandinin, Gilberto Q. Conchas, Robert E. Floden, Mary M. Juzwik, Felice J. Levine, Simon W. Marginson, Mariana Souto-Manning, Olga M. Welch

First published 2013

by Routledge

711 Third Avenue, New York, NY 10017

Simultaneously published in the UK

by Routledge

2 Park Square, Milton Park, Abingdon, Oxon OX14 4RN

Routledge is an imprint of the Taylor \& Francis Group, an informa business

The right of the editor to be identified as the author of the editorial material, and of the authors for their individual chapters, has been asserted in accordance with sections 77 and 78 of the Copyright, Designs and Patents Act 1988.

All rights reserved. No part of this book may be reprinted or reproduced or utilised in any form or by any electronic, mechanical, or other means, now known or hereafter invented, including photocopying and recording, or in any information storage or retrieval system, without permission in writing from AERA.

Trademark notice: Product or corporate names may be trademarks or registered trademarks, and are used only for identification and explanation without intent to infringe.

\section{Library of Congress Cataloging-in-Publication Data}

International handbook of research on environmental education/edited by Robert Stevenson ... [et al.]. p. cm.

Includes bibliographical references and index.

1. Environmental education-Handbooks, manuals, etc. 2. Environmental sciences-Study and teaching-Handbooks, manuals, etc.

I. Stevenson, Robert.

GE70.I584 2012

363.70071--de23

2012029041

ISBN: 978-0-415-89238-4 (hbk)

ISBN: 978-0-415-89239-1 (pbk)

ISBN: 978-0-203-81333-1 (ebk)

Typeset in Times LT Std

Project Managed and Typeset by diacriTech 
This handbook is dedicated to the pioneers in the field of environmental education who had the foresight that education and learning are crucial in finding pathways that allow humanity to live on this planet in an equitable and just way without compromising its carrying capacity while maintaining the integrity of all species. 



\section{Contents}

Foreword

Acknowledgments

1 Introduction: An Orientation to Environmental Education and the Handbook 1 Robert B. Stevenson, Arjen E.J. Wals, Justin Dillon, and Michael Brody

Part A. Conceptualizing Environmental Education as a Field of Inquiry

Section I. Historical, Contextual, and Theoretical Orientations That Have Shaped Environmental Education Research

Annette Gough

2 The Emergence of Environmental Education Research: A "History" of the Field Annette Gough

3 Socioecological Approaches to Environmental Education and Research: A Paradigmatic Response to Behavioral Change Orientations

Regula Kyburz-Graber

4 Thinking Globally in Environmental Education: A Critical History Noel Gough

5 Selected Trends in Thirty Years of Doctoral Research in Environmental Education in Dissertation Abstracts International From Collections Prepared in the United States of America

Thomas Marcinkowski, Jennifer Bucheit, Vanessa Spero-Swingle, Christine Linsenbardt,

Jennifer Engelhardt, Marianne Stadel, Richard Santangelo, and Katherine Guzmon

6 Transformation, Empowerment, and the Governing of Environmental Conduct: Insights to be Gained From a "History of the Present" Approach

Jo-Anne Ferreira

Section II. Normative Dimensions of Environmental Education Research: Conceptions of Education and Environmental Ethics

Bob Jickling and Arjen E.J. Wals

7 Probing Normative Research in Environmental Education: Ideas About Education and Ethics Bob Jickling and Arjen E.J. Wals

8 Self, Environment, and Education: Normative Arisings Michael Bonnett

9 A Critical Theory of Place-Conscious Education David A. Greenwood 
10 Learning From Hermit Crabs, Mycelia, and Banyan: Schools as Centers of Critical Inquiry and Renormatization

Heesoon Bai and Serenna Romanycia

11 Why We Need a Language of (Environmental) Education Lesley Le Grange

12 Environmental Ethics as Processes of Open-Ended, Pluralistic, Deliberative Enquiry Lausanne Olvitt

\section{Section III. Analyses of Environmental Education Discourses and Policies}

Ian Robottom and Robert B. Stevenson

13 The Politics of Needs and Sustainability Education Lesley Le Grange

14 Languages and Discourses of Education, Environment, and Sustainable Development Tom Berryman and Lucie Sauvé

15 Researching Tensions and Pretensions in Environmental/Sustainability Education Policies: From Critical to Civically Engaged Policy Scholarship

Robert B. Stevenson

16 Changing Discourses in EE/ESD: A Role for Professional Self-Development Ian Robottom

17 Connecting Vocational and Technical Education With Sustainability Alberto Arenas and Fernando Londoño

18 Trends, Junctures, and Disjunctures in Latin American Environmental Education Research Edgar González Gaudiano and Leonir Lorenzetti

19 EE Policies in Three Chinese Communities: Challenges and Prospects for Future Development Lee Chi Kin John, Wang Shun Mei, and Yang Guang

\section{Part B. Research on Environmental Education Curriculum, Learning,} and Assessment: Processes and Outcomes

\section{Section IV. Curriculum Research in Environmental Education \\ Heila Lotz-Sisitka}

20 Traditions and New Niches: An Overview of Environmental Education Curriculum and Learning Research Heila Lotz-Sisitka, John Fien, and Mphemelang Ketlhoilwe

21 Environmental Education in a Cultural Context Albert Zeyer and Elin Kelsey

22 Place-Based Education: Practice and Impacts

Gregory A. Smith

23 Getting the Picture: From the Old Reflection-Hearing Pictures and Telling Tales, to the New Reflection-Seeing Voices and Painting Scenes

Tony Shallcross and John Robinson

24 Moinho D'Água: Environmental Education, Participation, and Autonomy in Rural Areas João Luiz de Moraes Hoeffel, Almerinda B. Fadini, M.K. Machado, J.C. Reis, and F.B. Lima 
Section V. Research on Learning Processes in Environmental Education

Justin Dillon, Joe E. Heimlich, and Elin Kelsey

25 Environmental Learning: Insights From Research Into the Student Experience

Cecilia Lundholm, Nick Hopwood, and Mark Rickinson

26 Conventional and Emerging Learning Theories: Implications and Choices for Educational Researchers With a Planetary Consciousness

Arjen E.J. Wals and Justin Dillon

27 Belief to Behavior: A Vital Link

Joe E. Heimlich, Preethi Mony, and Victor Yocco

28 Landscapes as Contexts for Learning

Carol B. Brandt

Section VI. Evaluation and Analysis of Environmental Education Programs, Materials, and Technologies and the Assessment of Learners and Learning

Michael Brody and Martin Storksdieck

29 Research on the Long-Term Impacts of Environmental Education

Kendra Liddicoat and Marianne E. Krasny

30 Advancing Environmental Education Program Evaluation: Insights From a Review of Behavioral Outcome Evaluations

Michaela Zint

31 National Assessments of Environmental Literacy: A Review, Comparison, and Analysis

Thomas Marcinkowski, Donghee Shin, Kyung-Im Noh, Maya Negev, Gonen Sagy,

Yaakov Garb, Bill McBeth, Harold Hungerford, Trudi Volk, Ron Meyers, and

Mehmet Erdogan

32 Geospatial Technologies: The Present and Future Roles of Emerging Technologies in Environmental Education

Michael Barnett, James G. MaKinster, Nancy M. Trautmann, Meredith Houle Vaughn, and Sheron Mark

33 Sustainability Education: Theory and Practice

Sarah Holdsworth, Ian Thomas, and Kathryn Hegarty

34 Learning From Neighboring Fields: Conceptualizing Outcomes of Environmental Education Within the Framework of Free-Choice Learning Experiences

Lynn D. Dierking, John H. Falk, and Martin Storksdieck

Part C. Issues of Framing, Doing, and Assessing in Environmental Education Research

Section VII. Moving Margins in Environmental Education Research

Constance L. Russell and Leesa Fawcett

35 Researching Differently: Generating a Gender Agenda for Research in Environmental Education Annette Gough

36 The Representation of Indigenous Knowledges Soul Shava

37 Educating for Environmental Justice Randolph Haluza-DeLay 
38 Indigenous Environmental Education Research in North America: A Brief Review

Greg Lowan-Trudeau

39 Three Degrees of Separation: Accounting for Naturecultures in Environmental Education Research

Leesa Fawcett

\section{Section VIII. Philosophical and Methodological Perspectives}

Paul Hart

40 (Un)timely Ecophenomenological Framings of Environmental Education Research

Phillip G. Payne

41 Children as Active Researchers: The Potential of Environmental Education Research Involving Children

Elisabeth Barratt Hacking, Amy Cutter-Mackenzie, and Robert Barratt

42 Collaborative Ecological Inquiry: Where Action Research Meets Sustainable Development

Hilary Bradbury-Huang and Ken Long

43 Critical Action Research and Environmental Education: Conceptual Congruencies and Imperatives in Practice

Robert B. Stevenson and Ian Robottom

44 A Feminist Poststructural Approach to Environmental Education Research

Bronwyn Davies

45 Suited: Relational Learning and Socioecological Pedagogies

Marcia McKenzie, Kim Butcher, Dustin Fruson, Michelle Knorr, Joshua Stone, Scott Allen, Teresa Hill,

Jeremy Murphy, Sheelah McLean, Jean Kayira, and Vince Anderson

46 Greening the Knowledge Economy: Ecosophy, Ecology, and Economy

Michael A. Peters

47 Preconceptions and Positionings: Can We See Ourselves Within Our Own Terrain?

Paul Hart

\section{Section IX. Insights, Gaps, and Future Directions in Environmental Education Research}

48 The Evolving Characteristics of Environmental Education Research

Robert B. Stevenson, Justin Dillon, Arjen E.J. Wals, and Michael Brody

49 Identifying Needs in Environmental Education Research

Alan Reid and William Scott

50 Handbooks of Environmental Education Research: For Further Reading and Writing

Alan Reid and Phillip G. Payne

51 Tentative Directions for Environmental Education Research in Uncertain Times

Arjen E.J. Wals, Robert B. Stevenson, Michael Brody, and Justin Dillon

Author Index

Subject Index

The Editors 


\section{Foreword}

This significant, informative, and engaging book on research in environmental education is being published at a critical time in U.S. history. It is a time when competing ideas and perspectives about how to respond to questions and concerns about the environment are hotly debated and often ridiculed. These competing and contentious ideas make it difficult to identify the research, innovations, and programs that can be used to create a sustainable environment and prevent further damage to it. The field of environmental education is an appropriate focal point for many of the concerns that are being raised about the environment. This Handbook will be instrumental in identifying what is known in environmental education research. It will also help researchers identify questions that need to be answered as issues ranging from climate change and its effect on biodiversity to nature conservation are widely discussed.

The editors of the International Handbook of Research on Environmental Education have collected in a single volume a wealth of information including statistics, analyses, and studies that describe the role that research can play in helping educators, researchers, policy makers, and students better understand the environmental issues that people around the world are confronting. This Handbook will be a particularly important resource for the research community and those trying to comprehend and to advance research on environmental education. Information that will help graduate students craft thoughtful and insightful research questions as well as information about research methods and techniques are interspersed throughout this Handbook. In addition, the Handbook provides a framework and a knowledge base for decision makers who need to make informed and thoughtful decisions about environmental education issues, and educators who need to make curricular decisions about what students need to know and understand about the environment.

The 51 chapters in this Handbook include a mix of established and new voices in environmental education research. They include scholars from six continents and 15 countries. These myriad voices created a Handbook that is, as the editors point out, "attentive to the diverse populations served by contemporary educational systems as well as to opportunities to engage individuals and communities in nonformal and informal learning contexts." The Handbook's chapters are grouped into nine sections. Each section addresses important dimensions of environmental education research, ranging from its historical and theoretical foundations to issues related to gender, race, and colonialism. In addition to chapters that establish the knowledge base in environmental education, the Handbook also includes chapters that discuss ethics, the politics of sustainability, environmental justice, and other topics that link research in environmental education to the work being done by scholars in contiguous fields. The result is a volume that encompasses new and divergent perspectives and insights on environmental education issues and research.

The AERA Handbook Series in Education Research was designed and implemented by the AERA Books Editorial Board. When the proposal for the International Handbook of Research on Environmental Education was approved for inclusion in the series, the members of the board were Robert E. Floden, Patrick B. Forsyth, Felice J. Levine, Gary J. Natriello, Carol Camp Yeakey, myself, and Robert J. Sternberg, who chaired the publications committee. The board now consists of D. Jean Clandinin, Gilberto Q. Conchas, Robert E. Floden, Mary M. Juzwik, Felice J. Levine, Simon W. Marginson, Mariana Souto-Manning, Olga $\mathrm{M}$. Welch, and myself.

The Handbook Series is part of a comprehensive AERA books publication program that aims to publish works that advance knowledge, expand access to significant research and research analyses and syntheses, and promote knowledge utilization. The series specifically seeks to publish volumes of excellence that are conceptually and substantively distinct. The volumes in the series "offer state-ofthe-art knowledge and the foundation to advance research to scholars and students in education research and related social science fields." When the Books Editorial Board issued its call for proposals for handbooks in education research, the editors of the International Handbook of Research on Environmental Education were among the first to respond. Their proposal was accepted after a substantive review and a revision process directed by the Books Editorial Board.

The following criteria outlined in guidelines for preparing handbook proposals were used to review the proposal for the International Handbook of Research on Environmental Education. First and foremost, the board examined 
the proposed Handbook in terms of whether it would provide an opportunity for readers to take stock of and advance their thinking about current and future directions of environmental education research. Second, the board focused on the extent to which the proposed Handbook would draw on the strongest research-including research both within and outside the United States. Third, the board was interested in the ability of the editors of the proposed Handbook to bring together a team of authors who could assess the knowledge base of environmental education research and do so with respect to the diverse populations served by contemporary educational systems. Finally, the board reviewed the proposed content of the Handbook to get a sense of the book's scope and the extent to which it would include a "critical analysis of the strengths and limitations of extant studies as well as address the essential tools and elements for research progress."

At the end of the review process, the board enthusiastically approved and moved the International Handbook of Research on Environmental Education into development. Support was given to the editors during the manuscript development process, and when the manuscript was complete, it was reviewed and approved for publication by the board. We are very pleased to make this comprehensive, well-conceptualized, and theoretically strong Handbook available to readers interested in research on environmental education. It advances both theory and practice in the field of environmental education and will help strengthen the quality of environmental education research as well as help educators better understand, identify, and design and implement curriculum on environmental issues.

On behalf of the AERA Books Editorial Board, I want to thank editors Robert B. Stevenson, Michael Brody, Justin Dillon, and Arjen E.J. Wals for their substantial investment in this research Handbook and for producing a timely and significant volume. Special thanks is also due to Todd Reitzel who worked closely with the board and the editors in bringing this Handbook to fruition. Finally I wish to thank the many authors and reviewers for their important contributions to this important publication.

\author{
Cherry A. McGee Banks \\ Chair, AERA Books Editorial Board \\ University of Washington Bothell
}




\section{Acknowledgments}

This first AERA International Handbook of Research on Environmental Education represents the collective endeavors of countless individuals. The credit for what you hold in your hands or see on your screen is shared by authors, section editors, critical friends, the broader (and wonderfully diverse) community of scholars within the field of environmental education, and colleagues at the American Educational Research Association and Routledge.

The book has its roots in what is now called the Environmental Education (EE) Special Interest Group of the American Educational Research Association (AERA) but which began life in the early 1990s as the Ecological and Environmental Education SIG. This group has grown to be one of the strongest SIGs in AERA and continues to provide a social and intellectual home for researchers in environmental education. We acknowledge the leadership of that group over the past two and a half decades.

The strength of the EE SIG encouraged Felice Levine, AERA's Executive Director, and the AERA Books Editorial Board to invite a contribution to their education research handbook series. It has to be said that this was some years ago and the book has taken a long time to emerge. Without their initial invitation and their unstinting support, this book would be nothing but an idea in a few people's heads.

The length of time from invitation to delivery partly represents the fact that there was an extensive process of consultation and collaboration with many environmental education scholars across the world. As we spell out in the Introduction, we held a series of meetings to discuss the structure and the content of the Handbook at two AERA annual meetings, at the research symposium of the
North American Association for Environmental Education, at the World Environmental Education Congress in South Africa, and at the Invitational Seminar on Research and Development in Environmental and Health Education in Switzerland. These meetings were characterized by thoughtful dialogue, critical insight, and a depth of unbridled collegiality which has supported us through the development of the Handbook.

From the dialogue and discussion emerged an open call for authors. Gradually a sense of order and cohesion emerged and, together with a devoted and determined group of section editors, the long process of writing, critique, editing, and pulling together led to this, the first ever AERA International Handbook of Research on Environmental Education.

To all those who helped us with the planning, who submitted ideas and abstracts, who wrote the chapters, who reviewed submissions and edited the sections, and who took the final drafts and turned them into something beyond words, we offer our unconditional thanks. To those who supported us through this process emotionally, we offer our unconditional love.

As coeditors we take responsibility for the errors and biases that you might find within the nine sections and more than 50 chapters. We have done our best and trust that future editors, authors, and publishers will build on the foundations that this volume represents.

Robert B. Stevenson Michael Brody Justin Dillon Arjen E.J. Wals 